Int. J. Dev. Biol. 54: 1405-1417 (2010)

doi: $10.1387 / \mathrm{ijdb} .093001 \mathrm{pg}$

\title{
Cajal's achievements in the field of the development of dendritic arbors
}

\author{
PABLO GARCÍA-LÓPEZ1,2,\#, VIRGINIA GARCÍA-MARÍN*,1,3,\#, RICARDO MARTÍNEZ-MURILLO1 \\ and MIGUEL FREIRE1 \\ ${ }^{1}$ Instituto Cajal, CSIC, Madrid, Spain, ${ }^{2}$ School of Visual Arts, New York, NY, USA and \\ ${ }^{3}$ Centro de Tecnología Biomédica, Universidad Politécnica de Madrid, Madrid, Spain
}

\begin{abstract}
In 1909, Cajal published an up-dated version in French (Cajal, 1909-1911) of his main work Texture of the Nervous System of Man and Vertebrates (Cajal, 1899-1904), considered the most important book devoted to the nervous system. Owing that last year was the centenary of this publication, we decided to produce an article focused on Cajal's description of the morphological changes that dendritic trees undergo during development. We will emphasize his brilliant hypotheses explaining the modelling of dendritic trees (the neurotropic hypothesis and the role of neuronal activity in the patterning of the dendritic trees), and the status of this topic in present day Neuroscience. Here, we will show original photographs taken from a selected collection of Cajal's slides housed in the Cajal Museum (Instituto Cajal, CSIC, Madrid, Spain) illustrating the principal changes in neuronal morphology at different stages of development of the spinal cord, cerebellum and cerebral cortex. We will also discuss Cajal's initial proposals regarding the influence of neurotropic substances (chemotactic hypothesis) and neural activity in the modelling of the dendritic tree, as well as the evidence that later confirmed these theories.
\end{abstract}

KEY WORDS: Cajal, development, dendritic arbor, dendritic spine

\section{Introduction}

Cajal's contributions to the Nervous Systems represent the roots of modern Neuroscience. This immense and exceptional body of work carried out mainly with the Golgi method, was summarized by Cajal in his opus magnum book Textura del Sistema Nervioso del Hombre y de los Vertebrados (Cajal, 18991904). Ten years later, a French larger and updated translation of this work entitled Histologie du Système Nerveux de l'Homme et des Vertébrés (Cajal, 1909-1911), allowed Cajal to publish a greater exposure of his findings. Actually, a centenary of this publication is hold and we felt the opportunity to review some of the important facts on dendritic development that were discussed in his book and that are valid to date.

Dendritic morphology is a critical determinant of neuronal function since the patterns of dendrite arborization determine the kinds of input that neurons receive. The dendritic arborization is largely established during development through a combination of an intrinsic genetic program, growth promoting signals (neurotrophins) that regulate the size of the arbor, chemotropic cues (neurotropins) that guide dendrites to their proper location, and neurite-neurite contacts that ensure proper representation of the dendritic field and the establishment of the appropriate synaptic contacts (Parrish et al., 2007). These developmental signals may interact to create the definitive arborization of the dendritic tree, which will then only be slightly modified during adulthood.

Cajal was pionnering to describe morphological changes in the dendritic tree during development. One of the principal sources of

\footnotetext{
Abbreviations used in this paper: BDNF, brain-derived neurotrophic factor; $\mathrm{Ca}^{2+}$ calcium; CICR, calcium induced calcium release; ErbB or EGFR, epidermal growth factor receptor; GTPasa, guanine nucleotide triphosphatase; MAP, Mitogen-activated protein; MEF2A, myocyte enhancer factor-2A; NGF, nerve growth factor; NMDA, N-methyl-D-aspartic acid; NRG, neuregulin; NT-3, Neurotrophin-3; NT-3/4, Neurotrophin-3/4; NT4/5, Neurotrophin-4/5; PI3,Phosphoinositide3; PSD-95, postsynaptic density protein 95; ROBO, roundabout protein; SEMA-3A, Semaphorin-3A; SLIT1, Slit homolog 1 protein; TrkB, tropomyosin-related kinase receptor.
}

*Address correspondence to: Virginia Garcia Marin. Instituto Cajal (CSIC), Avda. Doctor Arce 37, 28002 Madrid, Spain. Fax: +34-91-585-4754. e-mail: vgmarin@cajal.csic.es

\#Note: Both authors have equally contributed to this work.

Accepted: 29 January 2010. Final author corrected PDF published online: 12 January 2011.

ISSN: Online 1696-3547, Print 0214-6282

(c) 2011 UBC Press

Printed in Spain 


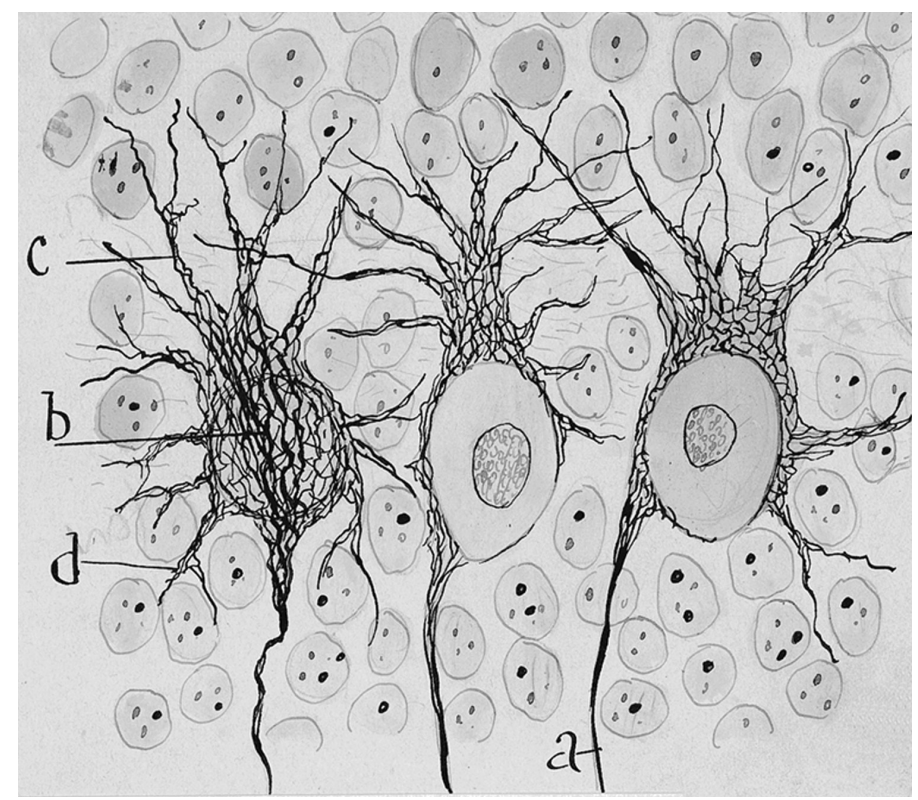

Fig. 1. Neurofibrils of Purkinje cells. Cajal's original drawing of Purkinje cells from a 3-4 day-old puppy (Cajal, 1903). Reduced silver nitrate staining method. Abbreviations: $a$, axon; $b$, stream of neurofibrils converging at the axon origin; $c$, neurofibrils of apical dendrites; $d$, neurofibrils of basal dendrites. Reproduced with the permission of the Inheritors of Santiago Ramón y Cajal.

Cajal's successes was to apply the ontogenic method to study the nervous system. Instead of studying the adult nervous system, he decided to work with embryos, young animals or simple animals, thereby reducing the complexity of the nervous structures. This approach had additional important advantages, both improving the consistency of the results obtained with the Golgi method (Golgi, 1873) and making it possible nerve fibers to be readily visualized. Embryonic axons are mostly unmyelinated, a morphological characteristic which permitted their stain following the Golgi method. By applying the ontogenic and Golgi methods, Cajal was able to describe the successive stages of the development of neurons and how they establish their connections. In his opera magna, "Textura del Sistema Nervioso del Hombre y de los Vertebrados"1 (Cajal, 1899-1904), after the chapters dealing with the spinal cord, cerebellum and cerebral cortex, there is a chapter explaining the development of the different types of neurons in these centers. This information allowed us focusing this article on the main findings reached by Cajal on dendritic arbor growth during the development of these regions.

Cajal used to work with embryos or young animals and contrasted the results with those obtained in the adult. Moreover, Cajal correlated his results following the Golgi method with those acquire by using other staining procedures, including Nissl, methylene blue and reduced silver nitrate stainings, particularly during development (Cajal, 1903a). In a later article (Cajal, 1903b), Cajal used the reduced silver nitrate staining to analyse the development of the cerebellum and cerebral cortex to depict specific modifications in the neuronal morphology during development together with changes in the neurofibrillar scaffold of the neurons (Fig. 1). As a result, he suggested that the cytoskeleton fulfilled an important role to support dendritic growth.

Although Cajal's histological slides provided only static images, Cajal anticipated that dendritic development is a dynamic process. Modern time-lapse imaging has confirmed this dynamism during dendritic development. The use of Zebrafish embryos and Xenopus tadpoles, and the possibility to observe axodendritic interactions thanks to genetic cell labeling techniques, have been fundamental to elucidate the mechanisms that operate behind the growth of the dendritic arbors (Rajan and Cline, 1998; Wu et al., 1999; Jontes and Smith, 2000; Niell et al., 2004). Timelapse imaging studies have shown that dendrite growth is a very dynamic process, with the continuous addition and retraction of branches, and that the dynamics of the arbor falls when it stops growing.

Furthermore, Cajal also proposed two mechanisms that might strongly influence the development of the dendritic tree: the neurotropic hypothesis (substances that exert a chemoattractic action) and activity mediated plasticity. According to Cajal, the secretion of "chemotactic factors" occurs during a brief period in the spinal cord that coincides with the emission of dendrites by the soma. Cajal also proposed that the initial tilt of commissural axons could be due to the secretion of attractive substances by the floor plate. These guidance substances were the first neurotropic factor identified as the Netrin family of proteins (Kennedy et al., 1994; Serafini et al., 1994; see García-Marín et al., 2009).

Advances in time-lapse imaging, electrophysiology and molecular biology have enabled the molecular mechanisms involved in neurotropic and activity dependent growth to be studied in greater detail, providing significant advances in our understanding of how these processes interact and are regulated.

\section{Dendritic development of spinal and bulbar motoneu- rons}

The initial stages of neuroblast maturation in the spinal cord were established by Cajal (1890c, 1899-1904) and Lenhossék (1891, Fig. 2). Cajal also recognized that there was a maturation gradient in the different divisions of the spinal cord. Thus, the motor roots in the ventral region develop earlier than the dorsal roots in the dorsal region and hence, the gelatinous substance of Rolando is the latter region to be developed. Neuroblasts in the spinal cord follow a series of stereotypic steps to form their

\footnotetext{
${ }^{1}$ Translated from the French version "Histologie" into English by:

Neely Swanson and Larry Swanson (1995). Histology of the Nervous system of Man and Vertebrales. New York, Oxford Universty Press. Pedro Pasik and Tauba Pasik (1999). Texture of the Nervous System of Man and Vertebrales. SpringerWien, New Cork, Springer Barcelona. Other Cajal's works translated into english are:

Javier DeFelipe and Edgard G. Jones, (1991). Cajal's Degeneration and Regeneration of the Nervous System. Translated by Raoul M. May. Edited by DeFelipe and Jones. Oxford Universty Press.

Javier DeFelipe and Edgard G. Jones, (1988).Cajal on the Cerebral Cortex. Translated by DeFelipe and Jones. Edited by Corsi, Jones and Sepherd. Oxford University Press.
} 
dendritic trees. Firstly, they emit an external prolongation from their piriform body directed towards the white matter with a growth cone at its tip (Cajal, 1890b; for a review on growth cone and Cajal see Garcia-Marin et al., 2009). This prolongation will later be the future axon (Cajal, 1899-1904). Accordingly to Cajal (1890c, 1899-1904) and Lenhossék (1891), the dendrites appear later and indeed, the dendrites of chick embryo motoneurons develop from the third day of incubation after the axon has arrived or is very close to its destination. These dendrites appear both at the opposite internal pole and in the initial shaft of the axon and some entering the white substance, terminating in a thick varicosity. During successive steps, the entire soma becomes covered by dendrites with new secondary and ternary branches. According to Cajal point of view, some of these branches will later be reabsorbed and retracted, especially those that penetrated the white substance. Finally, the dendrites shafts become covered by dendritic spines, as occurs on the 17th day of development in chick embryos. These morphological changes described by Cajal as necessary steps in the development of an adult neuronal dendritic tree in the spinal cord have been generally later confirmed in different types of motoneurons (Ulfhake et al., 1988; Lindsay et al., 1991a, b; Cameron et al., 1989, 1991; Curfs et al., 1993; Kalb, 1994; Nuñez-Abades and Cameron, 1995).

In view of Cajal, this morphological dendritic development was not continuous and gradual but rather it was a "construction and demolition" process (Cajal, 1899-1904, See Supplementary Quotations 1 and 2 at the end of this paper). Cajal hypothesized that the processes involved in the formation and elimination of new branches operated simultaneously (Cajal, 1899-1904). Significantly, the simultaneous "construction and demolition" theory by Cajal has been supported by recent studies based on time-lapse imaging of the retinotectal systems of Xenopus laevis, particularly those focused on the retinal ganglion cell axons and tectal dendrites (Rajan and Cline, 1998; Rajan et al., 1999; Hua and Smith, 2004).

In addition, Cajal suggested that afferent fiber connections are central to the stabilization and modeling of the dendritic tree. This hypothesis was later studied in greater detail by Vaughn using the spinal cord as a model too (Vaughn 1974, 1988, 1989). Vaughn's hypothesis suggests that branches are stabilized and stimulated to grow by synaptic contacts. Strong support for this hypothesis recently came from in vivo imaging of the optic tectum in zebrafish larvae, wherein stable dendritic branches contain PSD-95, suggesting that synapses readily stabilize branches. Furthermore, branch addition tends to occur near synaptic sites, which suggest that synaptic inputs promote branch addition (Niell et al., 2004). In this model, stabilized filopodia mature into dendritic branches and successive iteration of this process results in the growth and branching of the arbor (Niell et al., 2004). The molecular mechanisms that mediate this developmental plasticity (both spontaneous and environmentally evoked) have been studied in depth by the group of Kalb (Kalb, 1994; Inglis et al., 1998, 2000, 2002; David et al., 2005; Xiong et al., 2007).

The involvement of neurotropic factors in the development of the motoneuron dendritic tree was predicted by Cajal. Cajal prompted his hypothesis in his work on the retina (Cajal, 1893), initially known as the chemotactic hypothesis. He considered this hypothesis as a general rule for the development of neuronal processes (both dendrites and axon) and the migration of the cell somata of different types of neurons in the central nervous system (retina, granule and Purkinje cells of the cerebellum, pyramidal cells of the cortex, etc.). In the chapter concerning the development of the spinal cord published in the Cajal's book Textura (Cajal, 1899-1904), Cajal considered that these neurotropic substances and their effects on neuronal processes could influence on the final morphology of a particular adult neuron (See Supplementary Quotation 3). This theory that neurotropic mechanisms influence dendritic development complements Cajal's thinking about the importance of the nervous activity in the modeling and stabilization of the dendrite branching. Thus, today is known that the activitiy-dependent neurotrophic factors such as nitric oxide (Xiong et al., 2007) and also androgens (Goldstein et al., 1990) affect motoneuron development.

\section{Cerebellum dendritic development}

In his first article using the Golgi method, Cajal described the histological organization of the cerebellum providing anatomical data supporting the Cajal's neuron doctrine (Cajal, 1888a). In successive articles (Cajal, 1888a-c, 1889a, b, 1890a, 18991904), Cajal described the different types of fibers (climbing fibers, parallel fibers, mossy fibers, basket fibers, etc.), and the neuronal articulation between these processes and their targets (Purkinje cells, basket and stellate cells, Golgi cells, granule cells, etc.). The development of the dendritic tree of these neurons, especially Purkinje and granule cells, was accurately described by Cajal.

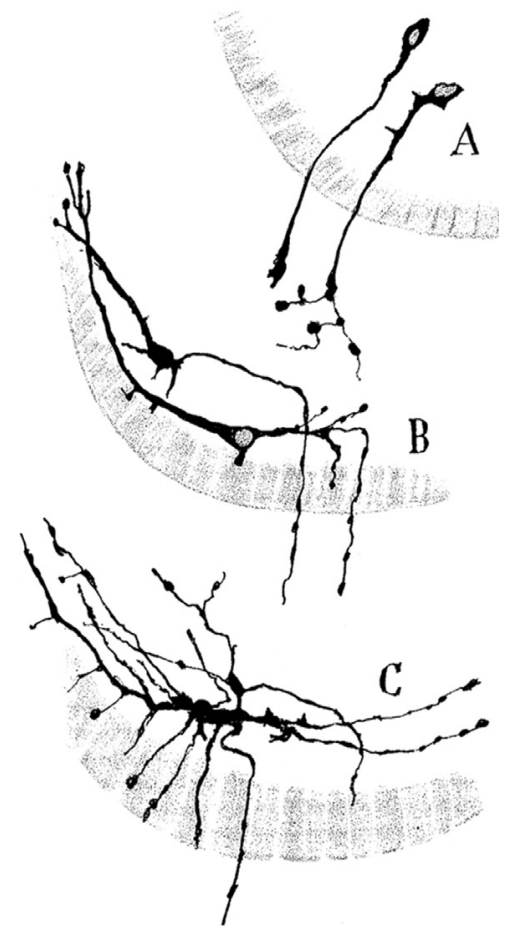

Fig. 2. Developmental stages of motoneurons. Cajal's original drawing illustrating the developmental stages of motoneurons in the chick embryo (Cajal, 1903). Golgi method staining. Neurons on the third(A), fourth (B) and fifth day (C) of incubation are drawn. Reproduced with the permission of the Inheritors of Santiago Ramón y Cajal. 


\section{The Purkinje cell}

Cajal described different successive steps in the development of the Purkinje cell: i) fusiform corpuscle phase, ii) stellate phase with disoriented dendrites, iii) phase of orientation and systematization of dendrites, and iv) adult phase (Cajal, 1899-1904, Cajal, 1926, see Sotelo, 2004, Fig. 3). During this developmental process many lateral immature dendrites that emerge from the soma (some of them exhibiting dendritic spines) are reabsorbed. These different stages of Purkinje cell development have been confirmed in more recent studies (Zecevic and Rakic, 1974; Purpura et al., 1964; Laxson and King, 1983; Dadoune, 1966; Altman, 1976; Armengol and Sotelo, 1991; Sotelo, 2004). It should be noted that some researchers (Sotelo, 2004; Boukhtouche et al., 2006) recognize an intermediate phase, called phase of regressive atrophic dendrites, between the fusiform and the stellate phases.

Cajal proposed that parallel and climbing fibers are implicated in the modeling of Purkinje trees. He observed Purkinje cells in different stages of development (stellate stage and stage of orientation and systematization of dendrites) in the same folia of the cerebellum. Cajal's point of view was that these temporal differ-

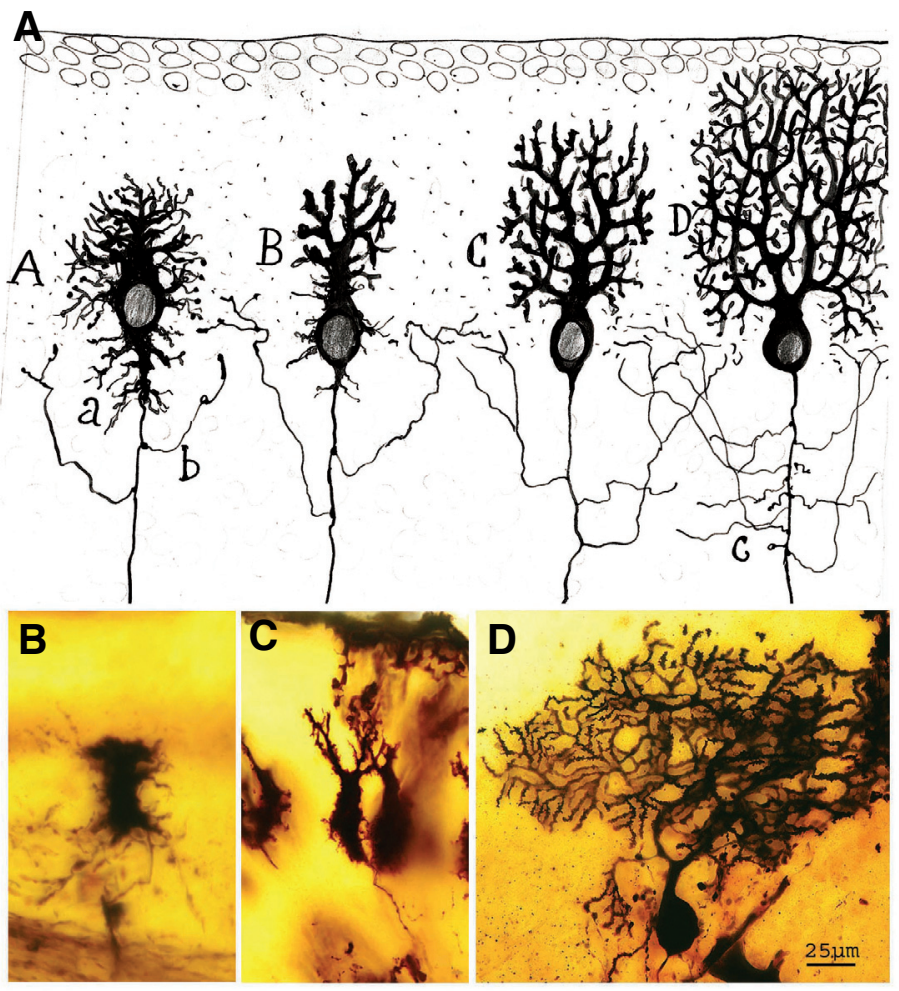

Fig. 3. Developmental stages of Purkinje cells. (A) According to Cajal drawings (1903), phases of the complication of the dendritic tree of a Purkinje cell. Abbreviations: a, provisional dendrites; $b$, axon collateral; $c$, exuberant axon collaterals. The successive stages in the maturation of the dendritic tree are the stellate phase (A), phase of orientation and systematization of dendrites (B), young Purkinje cell phase (C), and adult phase (D). (B-D) Photographs taken from Cajal's original histological preparations stained with the Golgi method. (B) The phase of initial dendrite disorientation (new-born puppy). (C) The phase of orientation and systematization of dendrites (new-born puppy). (D) Young Purkinje cell phase (from a young cat, almost adult). (Obj 40X, NA 1.0). Fig 3 A reproduced with the permission of the Inheritors of Santiago Ramón y Cajal. ences in development were due to neuronal activity generated in the connections established between Purkinje cells with both parallel and climbing fibers. Characteristically, Purkinje cells that do not contact with parallel and climbing fibers remain in an embryonic state (See Supplementary Quotation 4). In the article in which Cajal described his chemotactic hypothesis (Cajal, 1893), he anticipated the neurotropic action exerted by developing parallel fibers on the Purkinje cell dendritic tree. Later, Cajal (18991904) proposed that this shaping exerted by parallel and climbing fibers on Purkinje dendritic tree is mediated by neurotropic mechanisms, activity dependent plasticity or both. In his last article addressing this topic (Cajal, 1926), Cajal maintains this hypothesis although he thought that the neurotropic action was mediated by undifferentiated granule cells of the external granule cell layer.

\section{The role of climbing fibers in Purkinje cell morphogenesis}

Electron microscopy studies have shown that Purkinje cells receive some synaptic contacts during the fusiform stage of development, mainly from climbing fibers but also from parallel fibers (Laxson and King, 1983; Chedotal and Sotelo, 1992). During the successive developmental stages described by Cajal (Fig. 4), climbing fibers (nest phase) are initially associated with either the perisomatic spines (Larramendi and Victor, 1967) or perisomatic dendrites (Laxson and King, 1983). Later, these climbing fibers translocate to the upper side of the soma (capuchon stage) and then to the primary dendrites (mature arborization) of the Purkinje cells, where they establish synaptic contacts with clusters of dendritic spines (Larramendi and Victor, 1967). Cajal correlated the development of climbing fiber with the successive developmental states of Purkinje cells in terms of a neurotropic mechanism (Cajal, 1899-1904, Fig. 4). In the words of Cajal, the climbing fibers smell the Purkinje cells (Cajal, 1923, See Supplementary Quotations 5 and 6 ). The tropic activity of Purkinje cells on climbing fibers was evince in experiments involving unilateral pedunculotomy, when transcommissural climbing fibers rapidly innervate the denervated Purkinje cells (Lohof et al., 2005).

The role of climbing fiber in the developmental maturation of the Purkinje cell dendritic tree has been investigated by removing the olivary afferents (Sotelo and Arsenio-Nunes, 1976; Berry and Bradley, 1976). This experimental manipulation reduces the size of Purkinje cell dendritic tree although interestingly there were more dendritic spines on the proximal dendrites and these were contacted by parallel fibers. Recent experiments that have taken advantage of the blocking activity of tetrodotoxin (Morando et al., 2005) also demonstrated an increase in the number of dendritic spines on proximal branches that are then innervated by parallel fibers. However, these effects of the climbing fibers could be mediated by trophic support rather than by neural activity, because in experiments of slow-Wallerian degeneration in rats the formation of new spines in blocking activity conditions did not occur until the presynaptic climbing terminals had separated from their targets (Cesa et al., 2005).

\section{The role of parallel fibers in Purkinje cell morphogenesis}

The role of parallel fibers in modeling the dendritic tree has also been studied with the use of mutant animals and in the agranular cerebellum (Llinás et al., 1973; Sotelo et al., 1975; Sotelo, 1978; Crepel et al., 1980a, b; Hirano and Dembitzer, 1973). In the weaver and reeler mice, as well as in the rat cerebellum rendered agranular 
by postnatal X-radiation, Purkinje cells must grow in an environment free of granule cells and, consequently, free of parallel fibers. In these circumstances, Purkinje cells are poorly aligned, with stunted, disoriented and, less branched dendrites and no terminal branchlets. In addition, when cultured alone in vitro, Purkinje cells develop small dendritic trees that rather than developing dendritic branches and spines, are only studded with filopodia (Baptista et al., 1994; Dunn et al., 1998). However, when co-cultured with granule cells they develop a bigger dendritic tree studded with spines. Furthermore, by blocking activity with tetradotoxin it was shown that the parallel fibers also appear to participate in maintaining the size of the dendritic spines in the adult animal (Harvey et al., 2005).

Cajal suggested (1893, 1899-1904) that both the neural activity and neurotropic mechanisms regulate this process. It is well known that the activity-dependent secretion of neurotrophins, including BDNF and NT-3 (Neveu and Arenas, 1996; Morrison and Mason, 1998; Shimada et al., 1998; Hirai and Launey, 2000), is a candidate to participate in this process. Parallel fibers constitute a great source of neurotrophins in the cerebellum (Lindholm et al., 1997; for a review see Sherrard and Bower, 2002). The action of BDNF and other neurotrophins may be very complex and regulated by activity dependent processes or cell-cell interactions, and as such their effects may vary in vitro (different culture mediums) and in vivo (Morrison and Mason, 1998; Shimada et al., 1998) experimental conditions.

\section{Development of granule cells}

Cajal described the successive stages in the evolution of the granule cell, from the germinal phase in the external granule cell layer until it becomes an internal granule cell and forms claw endings on its dendrites (Cajal, 1899-1904, Fig. 5). Cajal speculated that the migration of the granule cell from the external to the internal granule layer was controlled by neurotropic mechanisms (Cajal, 1893, Fig. 5 A,B). This hypothesis was later extensively studied. The combination of electron microscopy approach and the Golgi-impregnation has indicated that granule cell migration is guided by interactions with Bergmann glial fibers that traverse the developing molecular layer (Rakic, 1971). In addition to this interaction with glial cells several factors such as astrotactin, BDNF, Cyclin-dependent Kinase, Ephrin B, Neuregulin, etc. have been identified contributing to this process (reviewed in Komuro and Yocubova, 2003). The migration of the granule cell from the external to the internal granular layer was shown to follow a gradient of BDNF which is amplified in an autocrine manner and mediated by endosomes (Zhou et al., 2007). Recently, Rieger et al. (2009) show by time-lapse imaging in live zebrafish embryos that cerebellar granule cells migrate in chain-like structures and coherent migratory behav- ior by means of Cadherin-2 in a homotypic glia-independent manner.

Cajal noticed that the evolution of granule cells did not strictly correlate with their location. In the internal granule cell layer, adult granule cells may have 4 to 5 dendrites with claw endings, or they may remain in a more purely embryonic stage (phase of multiple radiation) with many dendrites emerging from the soma. This intermingling of granule cells at different stages of development was independent of the depth and, therefore, the age of such cells (Fig. $5 \mathrm{~A}, \mathrm{C}$ ). Cajal invoked the activity of mossy fibers to explain this fact, postulating that granule cells that had contacted the mossy fibers evolve to a more mature stage while those that did not, remain in an undifferentiated state (See Supplementary Quotation 7). However, Cajal did not specify whether the action of mossy fibers on granule cells was chemotactic, mediated by nervous activity, or both. Some neurotrophic substances have been proved that operate during granule cell differentiation. Thus, neurotrophins such as BDNF and NT4/5 promote neurite extension and survival of differentiated cerebellar granule cells in vitro mediated through tropomyosin-related kinase receptor type B (TrkB) (Gao et al., 1995; Tanaka et al., 2000). In addition, neuregulin ErbB receptor (NRG/ErbB) signalling regulates neurite outgrowth as well and controls the number of dendrites elaborated by granule cells in vivo (Rieff and Corfas, 2006). Maturation of granule cells also influences the differentiation of the dendrite ending from a cup-like to a claw-like structure. The factors that control this structural change are not well defined as yet, although a form of MEF2A that acts as a transcriptional repressor has been proved to participate in dendritic claw differentiation (Shalizi et al., 2006). This process may in some way be regulated by nervous activity and reciprocally the structural remodeling may have consequences for the physiological activity of the synapses.

\section{Cerebral cortex}

Like spinal cord motoneurons and granule and Purkinje cells of the cerebellum, the development of pyramidal cell morphology is highly stereotyped. The differentiation of pyramidal cell dendritic tree may be genetically regulated since cell cultures also repro-
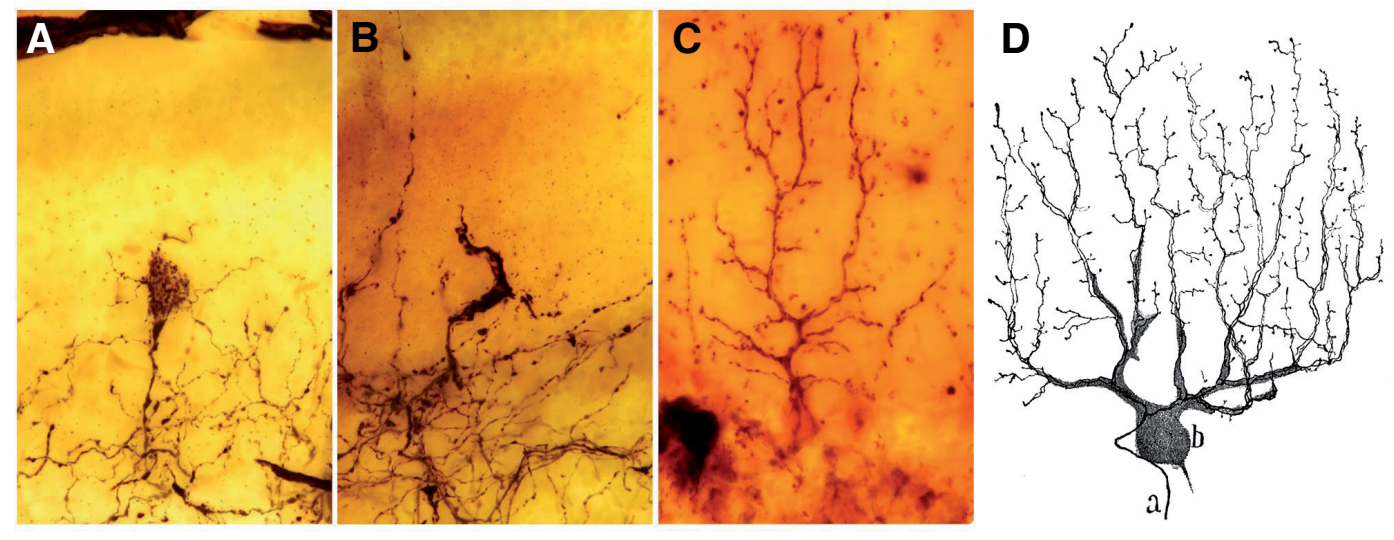

Fig. 4. Different phases of the maturation of the climbing fibers. (A) Nest perisomatic stage. (B) Supracellular hood stage (almost the young climbing fiber stage). (C) 8 Adult climbing fiber. (Obj. 40X NA1.0), Golgi Method. (A$C$ from Cajal's original histological preparations). (D) Drawing by Cajal of a Golgi-impregnated climbing fiber in the mature stage, human cerebellum, a, climbing fiber, b, Purkinje cell (Cajal, 1899-1904). Fig. 4D reproduced with the permission of the Inheritors of Santiago Ramón y Cajal. 
A
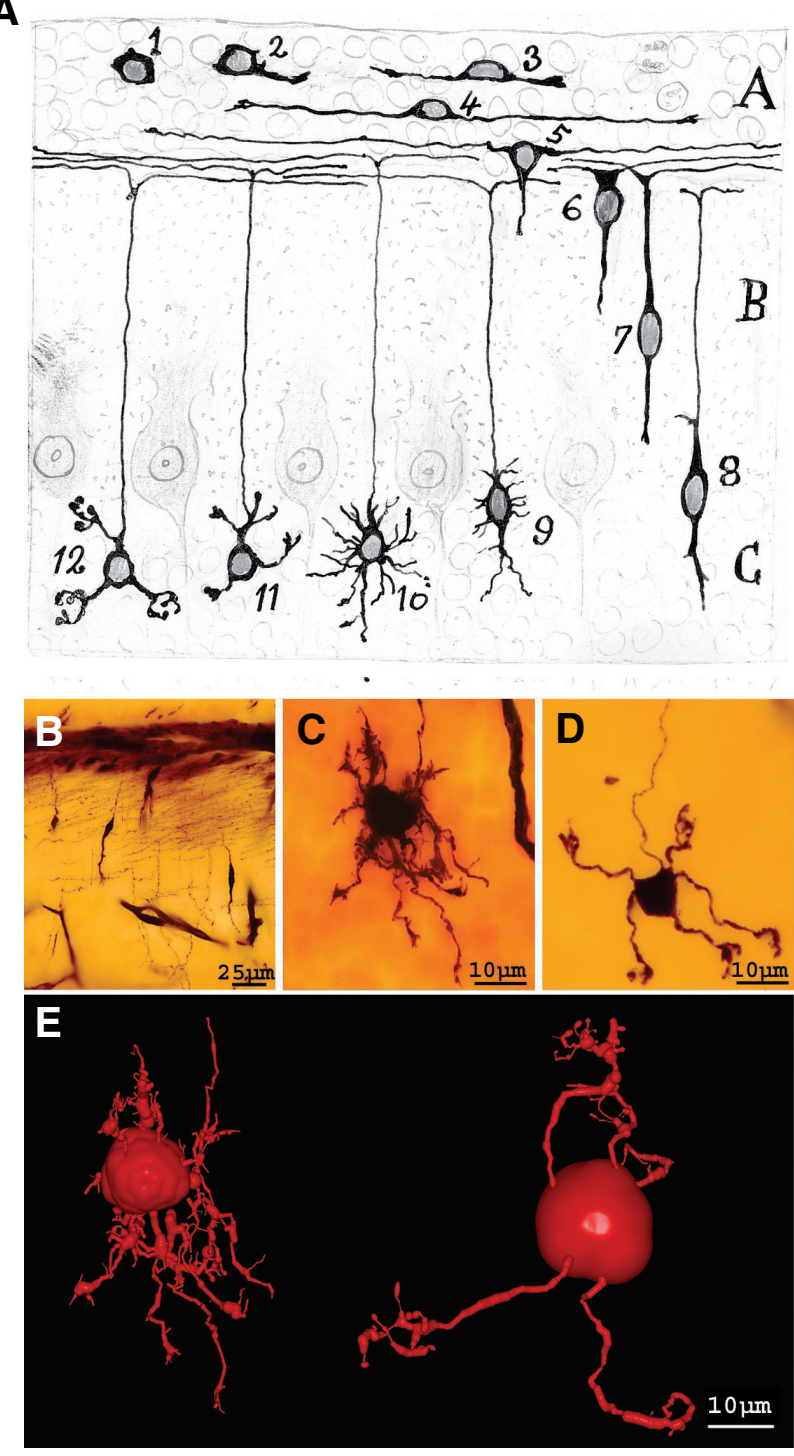

Fig. 5. Developmental stages of granule cells. (A) Migration and successive transformations of granule cells in the cerebellum as drawn by Cajal (Cajal, 1917). 1, germinal cell; 2 and 3, growth of polar expansions; 4, formation of bipolar horizontal; 5 and 6, progression of a descending expansion; 7 and 8, phase of vertical bipolarity; 9 and 10, formation of provisional dendrites; 11 and 12, modeling of the definitive processes. (BD) Photographs taken from Cajal's original slides stained with the Golgi method. (B) Migrating granule cells. (C) A young granule cell. (D) A mature granule cell. (E) Three-dimensional reconstruction of young (left hand) and mature (right hand) granule cells from Cajal's original slides. To reconstruct this Cajal neuron, we used an interactive light-microscope computer system for the three-dimensional (3D) reconstruction described in detail elsewhere (Garcia-Lopez et al., 2006). Briefly, optical sections (1280 x 1024 pixels) were taken from the preparation using a digital camera (DXM1200; Nikon, Tokyo, Japan), a motorized stage (ProScan H128; Prior Scientific, Rockland, MA), and a light microscope (Nikon Eclipse E600) with an oil immersion objective 100X, numerical aperture (NA) 1.4. The structures were coded as $3 D$ coordinates of selected points using the program Neuronal Coding (Freire, 1992). The code was converted with Persistence of Vision Raytracer (POV-Ray) for 3D rendering (Arellano and Freire, unpublished results). Fig $5 \mathrm{~A}$ reproduced with the permission of the Inheritors of Santiago Ramón y Cajal. duce their typical sequential development. Moreover, neurotropic and neurotrophic factors, can also regulate the patterning of pyramidal cell dendritic trees and the different morphologies found throughout different cortical layers.

\section{Developmental stages of pyramidal neurons}

Cajal made fundamental observations on the development of pyramidal cells in the cerebral cortex (Fig. 6). He showed that pyramidal neurons followed a stereotypic developmental program whereby the first extension from the soma forms the axon, which is followed by the emission of an apical dendrite that reaches layer I, the neurons thereby adopting a bipolar shape (Fig. 6D). Following the bipolar phase, the neurons emit the basal dendrites, the oblique branches of the apical trunk (firstly those more proximal to the soma) and also the apical tuft (Fig. 6C). Later in development, secondary dendrites, axon collaterals and dendritic spines appear (Fig. 6B, Cajal, 1899-1904). Through his studies with reduced silver nitrate staining, Cajal (1909-1911) also proposed the existence of two stages that preceded the bipolar phase, a primitive bipolar phase that would evolve into the neuroblast phase.

\section{Neurotropic and neurotrophic mechanisms that regulate pyramidal cell morphogenesis}

Cajal proposed that the growth of the apical trunk of the pyramidal cell towards the first layer could be explained by a neurotropic mechanism (Cajal, 1893; See Supplementary Quotation 8). Some of the molecular mechanisms that control the bipolar orientation of pyramidal cells in the cerebral cortex have been defined. Hence, the ventral growth of the axon and the pial growth of the apical dendrite are both mediated by a diffusible Semaphorine, Sema-3A, that is expressed in a gradient from its highest levels near the marginal zone (Polleux et al., 1998, 2000). Apart from Semaphorins, two other important families of chemotropic cues are Slits and Netrins. Slits are expressed at high levels in the cerebral cortex during development. Slit-1 interacts with roundabout (Robo) and increases dendritic growth and branching of pyramidal and non-pyramidal cells in cortical cultures (Whitford et al., 2002). By contrast, Netrin-1 acts as a chemoattractant for cortical axons in vitro (Métin et al., 1997; Serafini et al., 1996) although the expression of Netrin-1 in the cortical plate is low; making it unlikely that it exerts a significant effect on dendritic specification in the cerebral cortex (Whitford et al., 2002). Recent experiments suggest a role for Netrins in dendritic guidance. They have been implicated in guiding the dendrites of the zebrafish octavolateralis efferent neurons across the hindbrain midline (Suli et al., 2006) or guiding the contralateral dendrites of Drosophila aCC motoneurons that cross the midline (Kim and Chiba, 2004). Furthermore, other molecules such as Notch can inhibit dendritic growth in cortical neurons. Notch receptor activation is triggered by interneuronal contacts and it is sufficient to block dendritic growth (Sestan, 1999). Other experiments using antisense oligonucleotides (Redmond et al., 2000) suggest that Notch signalling mediates contact dependent inhibition of dendritic outgrowth. In addition to restricting length, Notch stimulates dendrite branching (Redmond et al., 2000).

Moreover, neurotrophins BDNF and NT-3/4 act as signaling molecules that regulate the growth and morphology of the dendritic trees in the cerebral cortex (McAllister et al., 1995; Baker et al., 1998). Exogenous BDNF and NT-3 increase the complexity of the 
dendritic tree of cortical pyramidal neurons by increasing the number of dendrites, branch points and the total dendrite length, especially in the basal rather than the apical dendrites (McAllister et al., 1995). Furthermore, cortical neurons overexpressing BDNF sprout many basal dendrites and they promote dendritic growth in nearby neurons (Horch and Katz, 2002). Interestingly, neurotrophins preferentially affect active neurons (McAllister et al., 1996, 1999). The activity-dependent action of neurotrophins provides a mechanism to selectively enhance dendrite growth in those neurons that are more active during development (McAllister et al., 1996). Furthermore, BDNF is released from hippocampal neurons in an activity-dependent manner (Balkowiec et al., 2002) and thus, neural activity may regulate neurotrophins secretion. The signalling mechanisms involved in BDNF dependent dendritic growth are not well understood, although some pathways have been studied. BDNF can activate the MAP-Kinase pathway and the phosphoinositide 3-Kinase (PI3K) pathway, which are both associated with the formation and stabilization of dendrites (reviewed in Dijkhuizen and Ghosh, 2005).

\section{Activity dependent plasticity in the cerebral cortex}

Nervous activity, either spontaneous or experience evoked, is an important factor that shapes the maturation of dendritic trees and synaptic connectivity during development (Katz and Shatz, 1996). Since early experiments of Wiesel and Hubel, the most extensively used model to study activity-dependent cortical development has been the visual cortex (Hubel and Wiesel, 1965a, b; Wiesel and Hubel, 1963, 1965a, b). In these initial experiments, the development of ocular dominance and binocularity in the primary visual cortex was shown to be influenced by sensory activity during a critical developmental period. In carnivores and primates, thalamic inputs to the cerebral cortex arising from the lateral geniculate nucleus (LGN) segregate within cortical layer IV into a series of ocular dominance columns corresponding to each eye. If one eye is deprived of sight, the patches of input from the LGN representing the open eye enlarge, while those representing the deprived eye become thinner. These experiments, along with others, demonstrated that visual deprivation can reduce the dendritic complexity of neurons in the visual cortex (Coleman and Riesen, 1968). Alternatively, exposure to an enriched environment can increase dendritic branching and spine density of pyramidal neurons (Holloway et al., 1996; Volkmar and Greenough, 1972, 1973; Stell and Riesen 1987; Globus et al., 1973). These effects remind us Cajal's original theories about plasticity.

Cajal introduced the concept of cerebral gymnastics (Cajal, 1892; Cajal, 1894; reviewed in DeFelipe, 2006) to explain the improvement experienced as a result of mental exercise based on the appearance of new associations between neurons (See Supplementary Quotations 9 and 10). He developed this theory by comparing the complexity of the dendritic trees in embryos and those in adults, and by considering the evolution of the pyramidal cell along the ontogenic scale (Cajal, 1892; Cajal 1894; reviewed in DeFelipe, 2006). In the Cajal's book Textura (Cajal, 1899-1904), in the chapter dedicated to the anatomic theories of the brain, Cajal based his theory of the "improved growth of interneuronal connections" on seven reasons. Three of them $(1,2,4)$ show the dynamic concept that Cajal had about the development of neuronal trees (See Supplementary Quotation 11). Cajal assumed the nervous system to be a very dynamic and a plastic structure, characteristics that are necessary during development, although diminished thereafter (Cajal, 1894).

The ultimate demonstration of the dynamic nature of the nervous system was provided by time-lapse imaging. During development, dendrites display significant branch extension and retraction (Dailey and Smith, 1996). Some of these branches proceed from stabilized filopodia that arise and retract from the dendrites (Dailey and Smith, 1996, Fig. 7). Indeed, there have been many studies providing evidence of previous Cajal's conclusions that dynamic behavior of dendrites diminishes as development proceeds (Dailey and Smith, 1996; Dunaevsky et al., 1999; for a review see Cline, 2001; Hua and Smith, 2004). Time-lapse imaging studies have also been essential to elucidate the role of nervous activity on the development of dendritic arbors and their dendritic appendages (dendritic filopodia and dendritic spines) in the cerebral cortex (Engert and Bonhoeffer, 1999; Maletic-Savatic et al., 1999; Lendvai et al., 2000).

In recent years, some of the molecular mechanisms involved in the dendritic tree dynamic during development have been elucidated. The Rho GTPases, regulators of the cytoskeletal stability, have emerged as key molecules in the integration of the enviromental cues that regulate dendritic patterning (Threadgill et al., 1997; Li et

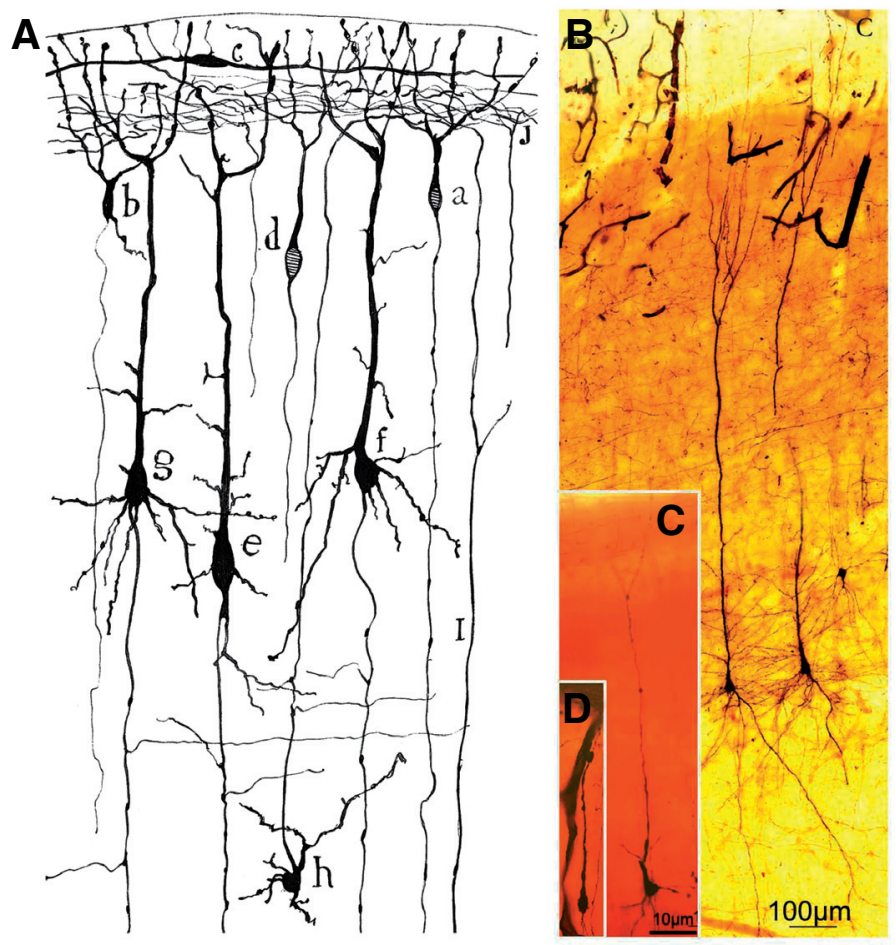

Fig. 6. Different maturation stages of pyramidal cells. (A) Cajal's drawing representing a coronal section through the cerebral cortex of a 4 day-old mouse (Cajal, 1899-1904) stained with the Golgi method; a, d, small pyramidal cells at the bipolar stage; b, a similar pyramidal cell, already with a descending dendrite; $\mathrm{c}$, horizontal cell in the molecular layer; I, a fiber coming from the white matter; j, terminal arborization of an ascending axon. (B-D) Photographs taken from Cajal's original histological preparations stained with the Golgi method. (B) pyramidal cells in the layer $V$ of a 15 day-old baby (Obj. 10X NA0.45). (C) Illustrates the growing of basilar dendrites of a new-born baby (Obj. 40X NA1.0). (D) Depict a bipolar neuron of a dog fetus (Obj. 40X NA1.0). Fig. 6A reproduced with the permission of the Inheritors of Santiago Ramón y Cajal. 


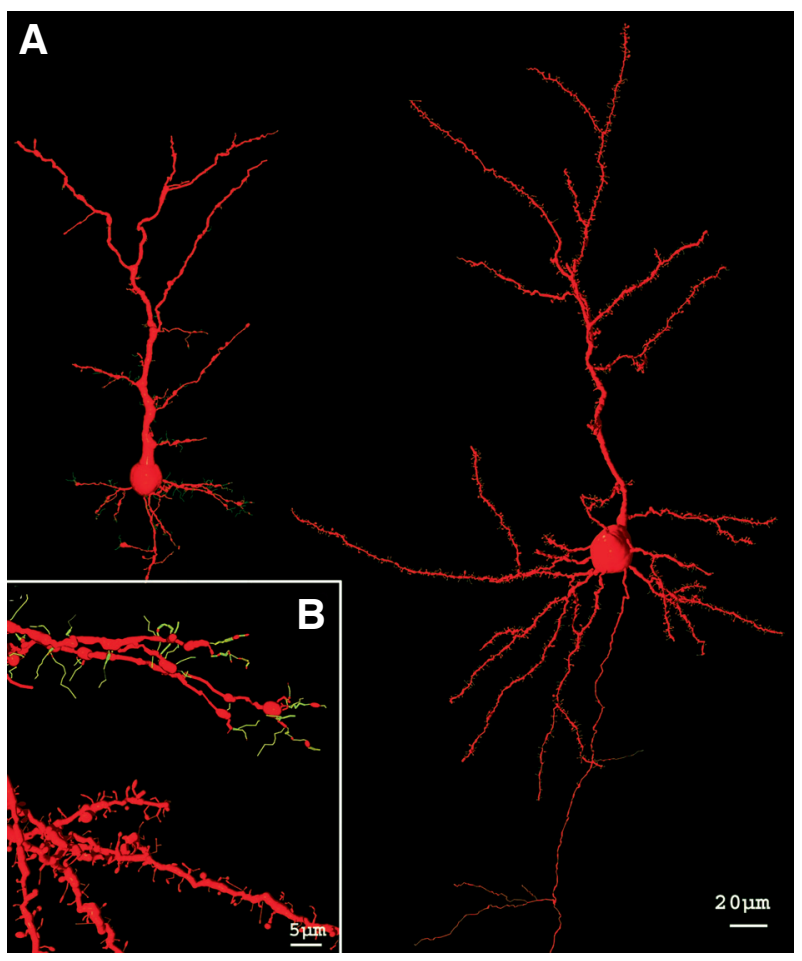

Fig. 7. Dendritic spines and filopodia of pyramidal cells. Threedimensional reconstruction of pyramidal cells acquired from Cajal's histological slides. (A) Represents pyramidal cells in a new-born rabbit (left hand) and young mouse (right hand) in layer III. (B) IIlustrates from top to bottom dendrites with filopodia (green) and dendritic spines (red) of a new-born rabbit and a young mouse, respectively. The tridimensional reconstructions have been generated as described in Fig. 5.

al., 2000, 2002; Van Aelst and Cline, 2004). The effects of neuronal activity on dendritic morphology are also mediated by $\mathrm{Ca}^{2+}$ signalling via two different mechanisms; long term dendritic growth requires $\mathrm{Ca}^{2+}$ influx through voltage-sensitive channels but not through NMDA receptors, and the synthesis of proteins (Redmond et al., 2002) whereas short term local dendritic development requires local increases of $\mathrm{Ca}^{2+}$ mediated by neurotransmission or by CICR (Calcium induced calcium release, Lohman et al., 2002). This second mechanism is suggested to mediate the dendritic growth regulated by afferent activity (for a review see: Dijkhuizen and Ghosh, 2005).

\section{Conclusion}

In this article, we have focused on the hypothesis raised by Cajal regarding the maturation of the dendritic tree in different areas of the nervous system (spinal cord, cerebellum and cerebral cortex). More than one hundred years ago, Cajal stated that both the nervous activity and neurotropic factors are pivotal during the development of neuronal arbors. In the context of neuronal development, modern studies have proved Cajal's theory. The role of activity-dependent neurotrophic factors (BDNF, NT-3, NT$3 / 4$, etc.), Rho GTPases and $\mathrm{Ca}^{2+}$ signalling together with neurotropic molecules (Semaphorins, Netrins, Slits, etc.) have been conclusively established in dendritic tree growth and differentiation. In addition, the maturation of the nervous system, including the formation of specific dendritic patterns, is spatially and locally regulated during development. Transcription factors are key regulators of these processes as they control the temporal and spatial expression of genes that determine the neuron reaction to neurotropic or synaptotropic signals.

\section{Acknowlegements}

We would like to acknowledge the inheritors of Santiago Cajal O. P. G$L$. is supported by the Fundación Caixa Galicia. This study was supported by grants from Spain's Ministry of Science and Innovation (SAF200760010) and the Instituto de Salud Carlos III (RETICS, RENEVAS, RD06/ 0026/1001).

\section{References}

ALTMAN J, MCCRADY B (1972). The influence of nutrition on neural and behavioral development. IV. Effects of infantile undernutrition on the growth of the cerebellum. Dev Psychobiol 5: 111-122.

ARMENGOL JA, SOTELO C (1991). Early dendritic development of Purkinje cells in the rat cerebellum. A light and electron microscopic study using axonal tracing in 'in vitro' slices. Brain Res Dev Brain Res 64: 95-114.

BAKER RE, DIJKHUIZEN PA, VAN PELT J, and VERHAAGEN J (1998). Growth of pyramidal, but not non-pyramidal, dendrites in long-term organotypic explants of neonatal rat neocortex chronically exposed to neurotrophin-3. Eur J Neurosci 10: 1037-1044.

BALKOWIEC A. KATZ DM (2002). Cellular mechanisms regulating activity-dependent release of native brain-derived neurotrophic factor from hippocampal neurons. J Neurosci 22:10399-407

BAPTISTA CA, HATTEN ME, BLAZESKI R, and MASON CA (1994). Cell-cell interactions influence survival and differentiation of purified Purkinje cells in vitro. Neuron 12: 243-260.

BERRY M, BRADLEY P (1976). The growth of the dendritic trees of purkinje cells in irradiated agranular cerebellar cortex. Brain Research 116: 361-387.

BOUKHTOUCHE F, JANMAAT S, VODJDANI G, GAUTHERON V, MALLET J, DUSART I, and MARIANI J (2006). Retinoid-related orphan receptor alpha controls the early steps of Purkinje cell dendritic differentiation. J Neurosci 26:1531-1538

CAJAL SR (1888a). Estructura de los centros nerviosos de las aves. Rev Trim Histol Norm Patol 1: 305-315.

CAJAL SR(1888b). Sobre las fibras nerviosas de la capa molecular del cerebelo. Rev Trim Histol Norm Patol 2: 33-49.

CAJAL SR (1888c). Estructura del cerebelo. Gác Méd Catalana 11: 449-457.

CAJAL SR (1889a). Sobre las fibras nerviosas de la capa granulosa del cerebelo. Rev Trim Histol Norm Patol 1: 107-118.

CAJAL SR (1889b). Conexión general de los elementos nerviosos. La Medicina Práctica 88: 341-346

CAJAL SR (1890a). Sobre ciertos elementos bipolares del cerebelo joven y algunos detalles más acerca del crecimiento y evolución de las fibras cerebelosas. Gac. San. Barcelona 2: 208-217; 233-243.

CAJAL SR (1890b). Sobre la aparición de las expansiones célulares en la médula embrionaria. Gac. Sanit Barcelona 2: 413-419.

CAJAL SR (1890c). A quelle époque appairaissent les expansions des cellules nerveuses de la moelle épinière du poulet? Anat. Anz 5: 609-613; 631-639.

CAJAL SR (1892). El nuevo concepto de la histología de los centros nerviosos. Rev Cienc Med Barcelona 18: 361-376, 457-476, 505-520,539-541.

CAJAL SR (1893). La rétine des vertebres. La Cellule 9: 121-255.

CAJAL, S.R. (1894). Consideraciones generales sobre la morfología de la célula nerviosa. Moya. Madrid.

CAJAL, S.R. (1899-1904). Textura del sistema nervioso del hombre y de los vertebrados. Moya, Madrid.

CAJAL SR (1903a). Sobre un sencillo proceder de impregnación de las fibrillas interiores del protoplasma nervioso. Arch Lat Méd Biol 1: 1-8.

CAJAL SR (1903b). Un sencillo método de coloración del retículo protoplásmico y 
sus efectos en los diversos centros nerviosos de vertebrados e invertebrados. Trab Lab Inv Biol Univ Madrid 2: 129-221.

CAJAL, S.R. (1909-1911). Histologie dù Système Nerveux de I'homme et des vertébrés. Maloine, París.

CAJAL SR (1926). Sur les fibers mousseuses et quelques points douteux de la textura de l'écorce cérébelleuse. Trab Lab Inv Biol Univ Madrid 24: 215-251.

CAMERON WE, FANG H, BROZANSKI BS and GUTHRIE RD (1989). The postnatal growth of motoneurons at three levels of the cat neuraxis. Neurosci Lett 104: $274-280$.

CAMERON WE, HE F, KALIPATNAPU P, JODKOWSKI J S, and GUTHRIE RD (1991). Morphometric analysis of phrenic motoneurons in the cat during postnatal development. J Comp Neurol 314: 763-776.

CESA R, MORANDO L, and STRATA P (2005). Purkinje cell spinogenesis during architectural rewiring in the mature cerebellum. Eur J Neurosci 22: 579-586.

CHEDOTAL A, and SOTELO C (1992). Early development of olivocerebellar projections in the fetal rat using CGRP immunocytochemistry. Eur J Neurosci 4: 1159-1179.

CLINE HT (2001). Dendritic arbor development and synaptogenesis. Curr Opin Neurobiol 11: 118-126

COHEN S, LEVI-MONTALCINI R, and HAMBURGER V (1954). A nerve growth stimulating-factor isolated from sarcomas 37 and 180. Proc Natl Acad Sci USA 40: 1014-1018.

COLEMAN PD, RIESEN AH (1968). Environmental effects on cortical dendritic fields. I. Rearing in the dark. J. Anat. 102: 363-374.

CREPEL F, HAYE-BOUCHAUD N, DUPONT JL and SOTELO C (1980a). Dendritic and axonic fields of Purkinje cells in developing and $x$-irradiated rat cerebellum. A comparative study using intracellular staining with horseradish peroxidase. Neuroscience 5: 333-347.

CREPEL F, HAYE-BOUCHAUD N, GUASTAVINO JM and SAMPAIO I (1980b). Multiple innervation of cerebellar Purkinje cells by climbing fibers in staggered mutant mouse. Nature 283: 483-484.

CURFS MH, GRIBNAU AA, and DEDEREN PJ (1993). Postnatal maturation of the dendritic fields of motoneuron pools supplying flexor and extensor muscles of the distal forelimb in the rat. Development 117: 535-541.

DADOUNE JP (1966). Contribution to the study of the differentiation of Purkinje cells in the cerebellar cortex of white rats. Arch Anat Histol Embryol 49: 381-393.

DAILEY ME, SMITH SJ (1996). The dynamics of dendritic structure in developing hippocampal slices. J Neurosci 16: 2983-2994.

DAVID S, STEGENGA, SL, HU P, XIONG G, KERR E, BECKER KB, VENKATAPATHY S, WARRINGTON JA, and KALB RG (2005). Expression of serum- and glucocorticoid-inducible kinase is regulated in an experiencedependent manner and can cause dendrite growth. J Neurosci 25: 7048-7053.

DEFELIPE J (2006). Brain plasticity and mental processes: Cajal again. Nat Rev Neurosci 7: 811-817.

DIJKHUIZEN PA, GHOSH A (2005) Regulation of dendritic growth by calcium and neurotrophin signaling. Prog Brain Res 147: 17-27.

DUNAEVSKY A, TASHIRO A, MAJEWSKA A, MASON A and YUSTE R (1999). Developmental regulation of spine motility in the mammalian central nervous system. Proc Natl Acad Sci USA 96: 13438-13443.

DUNN ME, SCHILLING K and MUGNAINI E (1998). Development and fine structure of murine Purkinje cells in dissociated cerebellar cultures: dendritic differentiation, synaptic maturation, and formation of cell-class specific features. Anat Embryol (Berl) 197: 31-50.

ENGERT F and BONHOEFFER T (1999). Dendritic spine changes associated with hippocampal long-term synaptic plasticity. Nature 399: 66-70.

FREIRE M (1992). Interactive computer-assisted coding, three-dimensional reconstruction, and quantitative analysis of neuronal perikarya, processes, spines and varicosities. J Neurosci Methods 10:331-349.

GAO WQ, ZHENG JL, and KARIHALOO M (1995). Neurotrophin-4/5 (NT-4/5) and brain-derived neurotrophic factor (BDNF) act at later stages of cerebellar granule cell differentiation. J Neurosci 15: 2656-2667.

GARCIA-LOPEZP, GARCIA-MARIN V, and FREIRE M. (2006) Three-Dimensional Reconstruction and Quantitative Study of a Pyramidal Cell of a Cajal Histological Preparation. J Neurosci 26: $11249-11252$.
GARCIA-MARIN V, GARCIA-LOPEZ P, and FREIRE M. (2009). The growth cone as seen through Cajal's original histological preparations and publications. $J$ Hist Neurosci 18: 197-210.

GLOBUS A, ROSENZWEIG MR, BENNETT EL, and DIAMOND MC (1973). Effects of differential experience on dendritic spine counts in rat cerebral cortex. J Comp Physiol Psychol 82: 175-181.

GOLDSTEIN LA, KURZ EM, and SENGELAUB DR. (1990). Androgen regulation of dendritic growth and retraction in the development of a sexually dimorphic spinal nucleus $J$ Neurosci. 10: 935-946.

GOLGI C (1873). Sulla struttura della sostanza grigia del cervello. Gazz Med Lombarda 6: 244-246.

HARVEY RJ, MORANDO L, RASETTI R. and PIERGIORGIO S (2005). Spontaneous electrical activity and dendritic spine size in mature cerebellar Purkinje cells. Eur J Neurosci 21: 1777-1784.

HIRAI H, LAUNEY T (2000). The regulatory connection between the activity of granule cell NMDA receptors and dendritic differentiation of cerebellar Purkinje cells. J Neurosci 20: 5217-5224

HIRANO A, DEMBITZER HM. (1973). Cerebellar alterations in the weaver mouse $J$ Cell Biol 56: 478-486.

Holloway S, Feniuk W, Kidd EJ,'and Humphrey PP (1996). A quantitative autoradiographical study on the distribution of somatostatin sst2 receptors in the rat central nervous system using [125I]-BIM-23027. Neuropharmacology 35: 1109-1120.

HORCH HW, KATZ LC (2002). BDNF release from single cells elicits local dendritic growth in nearby neurons. Nat Neurosci 5: 1177-1184.

HUA JY, SMITH SJ. (2004). Neural activity and the dynamics of central nervous system development. Nat Neurosci 7: 327-332.

HUBEL DH, WIESEL TN (1965a). Binocular interaction in striate cortex of kittens reared with artificial squint. $J$ Neurophysiol 28: 1041-1059.

HUBEL DH, WIESEL TN (1965b). Receptive fields and functional architecture in two nonstriate visual areas (18 and 19) of the cat. J Neurophysiol 28: 229-289.

INGLIS FM, CROCKETT R, KORADA S, ABRAHAM WC, HOLLMANN M, and KALB RG (2002). The AMPA receptor subunit GluR1 regulates dendritic architecture of motor neurons. J Neurosci. 22: 8042-8051.

INGLIS FM, ZUCKERMAN KE, and KALB RG (2000). Experience-dependent development of spinal motor neurons. Neuron 26: 299-305.

INGLIS FM, FURIA F, ZUCKERMAN KE, STRITTMATTER SM and KALB RG (1998). The role of nitric oxide and NMDA receptors in the development of motor neuron dendrites. J Neurosci 18:10493-10501.

JONTES JD, SMITH SJ (2000). Filopodia, spines, and the generation of synaptic diversity. Neuron 27: 11-14.

KALB RG (1994). Regulation of motor neuron dendrite growth by NMDA receptor activation. Development. 120: 3063-3071

KATZ LC, SHATZ CJ (1996). Synaptic activity and the construction of cortical circuits. Science 274: 1133-1138.

KENNEDY TE, SERAFINI T, DE LA TORRE JR, and TESSIER-LAVIGNE M (1994). Netrins are difusible chemotropic factors for commisural axons in the embryonic spinal cord. Cell 78: 425-435.

KIM S, CHIBA A (2004). Dendritic guidance. Trends Neurosci 27: 194-202.

KOMURO H, YACUBOVA E (2003). Recent advances in cerebellar granule cel migration Cell Mol Life Sci 60: 1084-1098.

LARRAMENDI EM, VICTOR T. (1967). Synapses on the Purkinje cell spines in the mouse. An electronmicroscopic study. Brain Res 5: 15-30.

LAXSON LC, KING JS (1983). The development of the Purkinje cell in the cerebellar cortex of the opossum. J Comp Neurol. 214: 290-308.

LENDVAI B, EDWARD AS, BRIAN C and SVOBODA K (2000). Experiencedependent plasticity of dendritic spines in the developing barrel cortex in vivo. Nature 404: 876-881.

LENHOSSÉK M (1891). Zur Kenntniss der ersten Enstehung der Nervenzellen und Nerven fasern beim Vogelembryo. Verhandl Kong inn Med 10 $10^{\text {th }}$ 2: 115-124.

LEVI-MONTALCINI R (1952). Effects of mouse tumor transplantation on the nervous system. Ann New York Acad Sci 55: 330-343.

LI Z, AIZENMAN CD, and CLINE HT (2002). Regulation of Rho GTPases by crosstalk and neuronal activity in vivo. Neuron 33:741-750. 
LI Z, VAN AELST L, and CLINE HT (2000). Rho GTPases regulate distinct aspects of dendritic arbor growth in Xenopus central neurons in vivo. Nat Neurosci 3: 217-225.

LINDHOLM D, HAMNER S, and ZIRRGIEBEL U (1997). Neurotrophins and cerebellar development. Persp Dev Neurobiol 5: 83-94.

LINDSAY AD, BINDER MD (1991a). Distribution of effective synaptic currents underlying recurrent inhibition in cat triceps surae motoneurons. J Neurophysiol 65: 168-177.

LINDSAY AD, GREER JJ and FELDMAN JL (1991b). Phrenic motoneuron morphology in the neonatal rat. J Comp Neurol 308: 169-179.

LLINÁS R, HILLMAN DE and PRECHT W (1973). Neuronal circuit reorganization in mammalian agranular cerebellar cortex. $J$ Neurobiol 4: 69-94.

LOHMAN C, MYTHR KL, and WONG RO (2002). Transmitter-evoked local calcium release stabilizes developing dendrites. Nature 418: 177-181.

LOHOF AM, MARIANI J, and SHERRAD RM (2005). Afferent-target interactions during olivocerebellar development: transcommissural reinnervation indicates interdependence of Purkinje cell maturation and climbing fibre synapse elimination. Eur J Neurosci 22: 2681-2688.

MALETIC-SAVATIC M, MALINOW R and SVOBODA K (1999). Rapid dendritic morphogenesis in CA1 hippocampal dendrites induced by synaptic activity. Science 283: 1923-1927.

MCALLISTER AK, KATZ LC and LO DC (1999). Neurotrophins and synaptic plasticity. Annu Rev Neurosci 22: 295-318

MCALLISTER AK, KATZ LC, and LO DC (1996). Neurotrophin regulation of cortical dendritic growth requieres activity. Neuron 17: 1057-1064.

MCALLISTER AK, LO DC, and KATZ LC (1995). Neurotrophins regulate dendritic growth in developing visual cortex. Neuron 17: 791-803.

MÉTIN C, DELÉGLISE D, SERAFINI T, KENNEDY TE and TESSIER-LAVIGNE M (1997). A role for netrin-1 in the guidance of cortical efferents. Development 124: 5063-5067.

MORANDO L, CESA R, HARVEY RJ, and STRATA P (2005). Spontaneous electrical activity and structural plasticity in the mature cerebellar cortex. Ann NY Acad Sci 1048: 131-140.

MORRISON ME, MASON CA (1998). Granule neuron regulation of Purkinje cell development: striking a balance between neurotrophin and glutamate signaling. J Neurosci 18: 3563-3573.

NEVEU I, ARENAS E (1996). Neurotrophins promote the survival and development of neurons in the cerebellum of hypothyroid rats in vivo. J Cell Biol 133: 631-646

NIELL CM, MEYER MP and SMITH SJ (2004) In vivo imaging of synapse formation on a growing dendritic arbor. Nat Neurosci 7: 254-260.

NUÑEZ-ABADES PA, CAMERON WE (1995). Morphology of developing rat genioglossal motoneurons studied in vitro: relative changes in diameter and surface area of somata and dendrites. J Comp Neurol 353: 129-142.

PARRISH JZ, KAZUO E, KIM M and NUNG JANG Y (2007). Mechanisms that regulate establishment, manteinance and remodeling of dendritic fields. Annu Rev Neurosci 30: 399-423.

POLLEUX F, MORROW T, and GHOSH A (2000). Semaphorin $3 A$ is a chemoattractant for cortical apical dendrites. Nature 404: 567-573.

POLLEUX F, GIGER RJ, GINTY DD, KOLODKIN AL, and GHOSH A. (1998). Patterning of cortical efferent projections by semaphorin-neuropilin interactions. Science 282: 1904-1906.

PURPURA DP, SHOFER RJ, and MUSGRAVE FS (1964). Cortical intracellular potentials during augmenting and recruiting responses. li. Patterns of synaptic activities in pyramidal and nonpyramidal tract neurons. J Neurophysiol27: 133151.

RAJAN I, WITTE S, and CLINE HT (1999). NMDA receptor activity stabilizes presynaptic retinotectal axons and postsynaptic optic tectal cell dendrites in vivo. J Neurobiol 38: 357-368.

RAJAN I, CLINE HT (1998). Glutamate receptor activity is required for normal development of tectal cell dendrites in vivo. J Neurosci 18: 7836-7846.

RAKIC P (1971). Neuron-glia relationship during granule cell migration in developing cerebellar cortex. A Golgi and electronmicroscopic study in Macacus Rhesus. J Comp Neurol 141: 283-312.

REDMOND L, KASHANI AH, and GHOSH A (2002). Calcium regulation of dendritic growth via CaM kinase IV and CREB-mediated transcription. Neuron 34: 999 1010.

REDMOND L, OH SR, HICKS C, WEINMASTER G and GHOSH A (2000). Nuclear Notch1 signaling and the regulation of dendritic development. Nat Neurosci 3 : 30-40.

RIEFF HI, CORFAS G (2006). ErbB receptor signalling regulates dendrite formation in mouse cerebellar granule cells in vivo. Eur J Neurosci 23: 2225-2229.

RIEGER S, SENGHAAS N, WALCH A, and KÖSTER RW (2009). Cadherin-2 Controls Directional Chain Migration of Cerebellar Granule Neurons. PLoS Biol 7(11): e1000240. doi:10.1371/journal.pbio.1000240.

SERAFINI T, KENNEDY TE, GALKO MJ, MIRZAYAN C, JESSELL TM, and TESSIER-LAVIGNE M (1994). The nectrins define a family of axon outgrowth promoting proteins homologous to C elegans Unc-6. Cell 78: 409-424.

SERAFINI T, COLAMARINO SA, LEONARDO ED, WANG H, BEDDINGTON R SKARNES WC and TESSIER-LAVIGNE M. (1996). Netrin-1 is required for commissural axon guidance in the developing vertebrate nervous system. Cell 87:1001-1014.

SESTAN N, ARTAVANIS-TSAKONAS S, and RAKIC P (1999). Contact-dependent inhibition of cortical neurite growth mediated by notch signaling. Science 286:741-746.

SHALIZI A, GAUDILLIÈRE B, YUAN Z, STEGMÜLLER J, SHIROGANE T, GE Q, TAN Y, SCHULMAN B, HARPER JW and BONNI A (2006). A CalciumRegulated MEF2 Sumoylation Switch Controls Postsynaptic Differentiation. Science 311: 1012-1017.

SHERRARD RM, BOWER AJ (2002). Climbing fiber development: Do neurotrophins have a part to play? Cerebellum 1: 265-276.

SHIMADA A, MASON CA, and MORRISON ME (1998). TrkB signaling modulates spine density and morphology independent of dendrite structure in cultured neonatal Purkinje cells. J Neurosci 18 8559-8570.

SOTELO C (2004). Cellular and genetic regulation of the development of the cerebellar system. Progress in Neurobiol. 72: 295-339.

SOTELO C (1978). Purkinje cell ontogeny: formation and maintenance of spines. Prog Brain Res 48: 149-170.

SOTELO C, ARSENIO-NUNES ML (1976). Development of Purkinje cells in absence of climbing fibers. Brain Res 111: 289-295.

SOTELO C, HILLMAN DE, ZAMORA AJ, and LLINAS R (1975). Climbing fiber deafferentation: its action on Purkinje cell dendritic spines Brain Research 98 574-581

STELL M, RIESEN A (1987). Effects of early environments on monkey cortex neuroanatomical changes following somatomotor experience: effects on layer III pyramidal cells in monkey cortex. Behav Neurosci 101: 341-346.

SULI A, MORTIMER N, SHEPHERD I, and CHIEN CB (2006). Netrin/DCC signaling controls contralateral dendrites of octavolateralis efferent neurons. J Neurosci 26:13328-13337.

TANAKA S, SEKINO Y, and SHIRAO T (2000). The effects of neurotrophin-3 and brain-derived neurotrophic factor on cerebellar granule cell movement and neurite extension in vitro. Neuroscience 97: 727-734.

THREADGILL R, BOBB K, and GHOSH A (1997). Regulation of dendritic growth and remodeling by Rho, Rac, and Cdc42. Neuron 19: 625-634.

ULFHAKE B, CULLHEIM S, and FRANSON P (1988). Postnatal development of cat hind limb motoneuronas. J. Comp Neurol. 278: 69-120.

VAN AELST L, CLINE HT (2004). Rho GTPases and activity-dependent dendrite development. Curr Opin Neurobiol. 14(3):297-304.

VAUGHN JE (1989). Fine structure of synaptogenesis in the vertebrate central nervous system. Synapse 3: 255-285.

VAUGHN JE, BARBER RP, and SIMS TJ (1988). Dendritic development and preferential growth into synaptogenic fields: a quantitative study of Golgiimpregnated spinal motor neurons. Synapse 2: 69-78.

VAUGHN JE, HENRIKSON CK and GRIESHABER JA (1974). A quantitative study of synapsis on motor neuron dendritic growth cone in developing mouse spinal cord. J Cell Biol 60: 664-672.

VOLKMAR FR, GREENOUGH WT (1972). Rearing complexity affects branching of dendrites in the visual cortex of the rat. Science 176: 1445-1447.

WHITFORD KL, MARILLAT V, STEIN E, GOODMAN CS, TESSIER-LAVIGNE M, 
CHÉDOTAL A. and GHOSH A (2002). Regulation of cortical dendrite development by Slit-Robo interactions. Neuron 33:47-61.

WIESEL TN, HUBEL DH (1965a). Comparison of the effects of unilateral and bilateral eye closure on cortical unit responses in kittens. J Neurophysiol 28:1029-1040.

WIESEL TN, HUBEL DH (1965b). Extent of recovery from the effects of visual deprivation in kittens. J Neurophysiol 28: 1060-1072.

WIESEL TN, HUBEL DH (1963). Effects of visual deprivation on morphology and physiology of cells in th cats lateral ginculate body.. Neurophisyol 26: 978-993.

WU GY, ZOU DJ, RAJAN I, and CLINE H (1999). Dendritic dynamics in vivochange during neuronal maturation. J Neurosci 19: 4472-4483.

\section{Supplementary Quotations}

1. "El soma del neuroblasto antes de la aparición de las arborizaciones nerviosas que con él deben entrar en contacto, emite dendritas que crecen en cualquier dirección siguiendo el sentido de menor resistencia ; pero en cuanto dichas arborizaciones perisomáticas y peridendríticas entran en escena, realízase un trabajo paralelo de creación y demolición, en virtud de la cual se establecerá la forma definitiva de la neurona"(Cajal, 1899-1904).

1. "Prior to the appearance of axonal arborizations with which it must establish contact, the soma of the neuroblast emits dendrites that grow in any direction following the path of least resistance; but as soon as the perisomatic and peridendritic axonal arborizations appear, the processes of construction and demolition occur in parallel to establish the definitive shape of the neuron" (Cajal, 1899-1904).

2. “...aquellas (expansiones) que acertaron á ponerse en contacto con fibrillas nerviosas terminales, se conservarán y desarrollarán, en tanto que aquellas otras que no tuvieron la suerte de establecer relaciones de contigüidad con las susodichas arborizaciones nerviosas se atrofiarán y desaparecerán” (Cajal, 1899-1904).

2. "...those processes that succeeded in coming into contact with terminal axonal fibers will be preserved and will develop further, whereas those that did not have the good fortune of establishing a contiguous relation with these nervous arborizations, will atrophy and disappear." (Cajal, 1899-1904).

3. "Por donde se ve que el sinnúmero de expansiones y conexiones intercelulares ofrecidas por el sistema nervioso adulto, cabe concebirse como expresión morfológica de los innumerables caminos trazados en el espacio y durante todo el período evolutivo,
XIONG, G., MOJSILOVIC-PETROVIC, J., PÉREZ, C.A., AND KALB, R.G. (2007). Embryonic motor neuron dendrite growth is stunted by inhibition of nitric oxidedependent activation of soluble guanylyl cyclase and protein kinase G. Eur J Neurosci 25: 1987-1997.

ZECEVIC, N., AND RAKIC, P. (1976). Differentiation of Purkinje cells and their relationship to other components of developing cerebellar cortex in man. $J$ Comp Neurol 167: 27-47.

ZHOU P, PORCIONATTO M, PILAPIL M, CHEN Y, CHOI Y, TOLIAS KF, BIKOFF JB, HONG EJ, GREENBERG ME, AND SEGAL RA. (2007). Polarized Signaling Endosomes Coordinate BDNF Induced Chemotaxis of Cerebellar Precursors. Neuron 55: 53-68.

por las corrientes de las materias reclamos". (Cajal, 1899-1904). 3. "It therefore appears that during the entire developmental period, the innumerable processes and intercellular connections in the adult nervous system can be interpreted as the morphologic expression of the infinite routes traced in space by currents of attractant substances." (Cajal, 1899-1904).

4. "La evolución de las células de Purkinje no se efectúa simultáneamente en todos los parajes de las laminillas cerebelosas.... el plegamiento cerebeloso, produce....al nivel de los surcos un aumento de la presión...haciendo difícil y tardía la emigración y diferenciación de los granos (los cuales por sus fibras paralelas influyen en el modelamiento del ramaje de Purkinje), y además retrasando y entorpeciendo el arribo y crecimiento de las fibras trepadoras. En virtud de estas condiciones mecánicas, toda célula que no haya podido establecer conexión con fibras paralelas y trepadoras, se mantiene en el estado embrionario, es decir en la fase de radiaciones dendríticas indiferentes, fase que precede, según hemos visto, al estadio de aplanamiento y diferenciación del ramaje protoplásmico". (Cajal, 1899-1904)

4 "The development of Purkinje cells does not occur simultaneously in all fields of the cerebellar folium...the cerebellar folding produces .... at the level of the sulci an increase of the pressure ... making difficult and late the emigration and differentiation of the grains (which by their parallel fibers influence the modelling of the Purkinje cell dendritic tree), and also, delay and hinder the arrival and growth of the climbing fibers. In the light of these mechanisms, any Purkinje cell that had not been able to establish connections with parallel and climbing fibers remains in an embryonic state, i.e. in the phase of undifferentiated dendritic radiations 
that precedes, according to what we have seen, the stage of flattening and differentiation of the dendritic tree." (Cajal, 18991904)

5. "Los axones de los mencionados conductores, arribados de centros lejanos, olfatean, digámoslo así, el soma de los elementos de Purkinje, al cual abrazan...." (Cajal, 1923).

5. "On reaching far-off centres, the aforementioned pioneer axons "smell", should we say the soma of the Purkinje cell, which it then surrounds ..." (Cajal, 1923).

6. “...á medida que el plexo trepador se disloca, cambia no sólo su forma, sino la riqueza de las ramas, circunstancia que induce á pensar que, á la manera de lo ocurrido en la arborización dendrítica primordial, muchos ramúsculos nerviosos iniciales se absorben, conservándose no más aquellos que pudieron entrar en conexión íntima con los tallos y ramas protoplásmicas últimamente formados". (Cajal, 1899-1904, 1909-1911).

6. "... as the climbing plexus becomes displaced, not only does it change its shape but also the richness of its branches, which suggests that like the primary dendritic arborization, many of the initial branchlets are reabsorbed, only those that could enter into close connection with the latter formed stems and dendrites persisting." (Cajal, 1899-1904, 1909-1911).

7. "Esta falta de orden cronológico en el modelamiento definitivo del grano, constituye un fenomeno facilmente concebible si imaginamos, como opina Cajal, que las fibras musgosas obran sobre los granos con quienes se ponen en contacto, provocando en ellos la formación de los apéndices digitiformes definitivos, $y$ determinando la absorción de los que, por no haberse puesto en contacto con rosáceas, resultan conductores enteramente superfluos. Acaso la acción sea cruzada: por un lado, y merced á una acción quimiotactica ó de otra especie, los granos influyen sobre la ramificación terminal de las musgosas, y por otro, éstas obran sobre las dendritas de los granos promoviendo su modelamiento definitivo. Los granos todavía indiferentes, es decir los que no yacen próximos á musgosa, mantiénense en estado fetal." (Cajal, 1899-1904; Terrazas, 1897).

7. "This lack of chronological order in the definitive modelling of the granule cell is a phenomenon easy to understand if we imagine, as Cajal does, that mossy fibres act on the granule cells with which they contact, promoting the formation of the definitive digitiform appendages and determining the absorption of those which having failed to contact rosettes, become entirely superfluous conductors. Perhaps this action is reciprocal: on the one hand, granules influence terminal ramifications of mossy fibers thanks to chemotactic or another mechanism while on the other hand, mossy fibers act on dendrites of granules to promote their definitive modelling. Still undifferentiated granules, i.e. those that do not lie close to a mossy fiber, remain in an embryonic state." (Cajal, 1899-1904; Terrazas, 1897).

8. "Car la disposition en fuseau des cellules de l'épendyme, bien connue actuellement par les travaux de Magini, Falzacappa, Cajal et Retzius, ainsi que la direction rayonnante des prolongements périphériqes s insérant dans la pia mater, pourrait influencer en quelque chose (à part la chimiotaxie) I'orientation et l'accroissement vers la surface cérébrale de la tige protoplasmique.» (Cajal, 1893)

8. "Due to the spindle-like shape of the ependymal cells, well documented in the studies of Magini, Falzacappa, Cajal et Retzious, and despite the radial orientation of their peripheral prolongations that insert into the pia mater, they may also influence (by chemotaxis) the orientation and the growth of the protoplasmic elongation towards the surface of the brain.» (Cajal, 1893)

9. "...la gimnasia cerebral ya que no puede producir células nuevas (las células nerviosas no se multiplican como las musculares) lleva un poco más allá de lo corriente el desenvolvimiento de las expansiones protoplásmicas y colaterales nerviosas, forzando el establecimiento de nuevas y más extensas conexiones intercorticales." (Cajal, 1892).

9. "...the cerebral gymnastics, given that the brain can no longer produce new nerve cells (the nervous cells do not multiply like those of the muscles), furthers the development of the protoplasmic extensions and nerve collaterals beyond that usually attributed to them, as they are forced to establish new and more extensive intercortical connections". (Cajal, 1892).

10. “...puede admitirse como cosa muy verosímil que el ejercicio mental suscita en las regiones cerebrales más solicitadas un mayor desarrollo del aparato protoplásmico y del sistema de colaterales nerviosas. De esta suerte las asociaciones ya establecidas entre ciertos grupos de células se vigorizarían notablemente por medio de la multiplicación de las ramitas terminales de los apéndices protoplásmicos y de las colaterales nerviosas; pero, además, gracias á la neoformación de colaterales y de expansiones protoplásmicas, podrían establecerse conexiones intercelulares completamente nuevas"(Cajal, 1894). 10. "...it could be accepted as highly likely that mental exercise causes a greater development of the [dendritic] apparatus and of the network of [axon] collaterals in the cerebral regions most in demand. Hence, the association that are already established between certain groups of cells would be notably strengthened by means of the multiplication of the small terminal branches of the [dendritic processes] and of the [axon] collaterals. However, thanks to the neoformation of [axon] collaterals and [dendritic processes], completly new intercellular connections could also be established". (Cajal, 1894, translated by Defelipe, 2006).

11. Three of the seven reasons $(1,2,4)$ argued by Cajal about the dynamic and the plastic structure of dendrites and axonal arborizations during the development:

"1․ Durante el desarrollo embrionario, las dendritas y ramificaciones nerviosas se extienden y ramifican progresivamente, poniéndose en contacto con un número cada vez mayor de neuronas (véase Histogénesis de la médula espinal, capítulo XXI, tomo I).

$2^{\circ}$. Es un hecho también que el ajuste definitivo de estas relaciones no se verifica sino después de algunos tanteos, advirtiéndose que antes de que las expansiones lleguen á su destino y creen articulaciones estables, desaparecen numerosas ramas accesorias, especie de asociaciones de ensayo cuya existencia prueba la gran movilidad inicial de las arborizaciones celulares... $4^{\circ}$. Este movimiento y crecimiento de las expansiones se continúa después del nacimiento, existiendo una gran diferencia en punto á longitud y caudal de ramificaciones neuronales secundarias y 
terciarias, entre el niño recién nacido y el hombre adulto". (Cajal, 1899-1904)

11. " 1 st During embryonic development, dendrites and axonal arborizations extend and ramify progressively, becoming in contact with an ever increasing number of neurons (see Histogenesis of the spinal cord, in Volume I, Chapter XXI).

$2^{\text {nd }}$ The final adjustments of these relationships occurs alter some attempts, and it is noted that before the processes arrive at their destination and create stable articulations, numerous accessory branches disappear. This sort of rehearsal of association proves the great initial mobility of cellular arborizations....

$4^{\text {th }}$ This movement and this growth of processes continues after birth, and there is a great difference in the length and amount of secondary and tertiary neuronal ramifications between the newborn infant and the adult human". (Cajal, 1899-1904)

\section{Further Related Reading, published previously in the Int. J. Dev. Biol.}

See our recent Special Issue Placenta edited by Joan S. Hunt and Kent L. Thornburg at: http://www.ijdb.ehu.es/web/contents.php?vol=54\&issue=2-3

Epithelial-Mesenchymal Transitions in development and disease: old views and new perspectives. M. Angela Nieto

Int. J. Dev. Biol. (2009) 53: 1541-1547

Contributions to Neuroembryology of Santiago Ramon y Cajal (1852-1934) and Jorge F. Tello (1880-1958).

Luis Puelles

Int. J. Dev. Biol. (2009) 53: 1145-1160

Early bases of modern Embryology in Spain: Microscopical Anatomy and the introduction of Cell Theory and Histology in their scientific and social European context.

Roberto Marco-Cuellar(†) and Juan Aréchaga

Int. J. Dev. Biol. (2009) 53: 1123-1143

Accessory nuclei in insect oogenesis: in search of the function of enigmatic organelles.

Mariusz K. Jaglarz, Malgorzata Kloc and Szczepan M. Bilinski

Int. J. Dev. Biol. (2008) 52: 179-185

Neurotrophic regulation of retinal ganglion cell synaptic connectivity: from axons and dendrites to synapses.

Susana Cohen-Cory and Barbara Lom

Int. J. Dev. Biol. (2004) 48: 947-956

Evidence that the rat osteopetrotic mutation toothless (tI) is not in the TNFSF11 (TRANCE, RANKL, ODF, OPGL) gene.

P R Odgren, N Kim, L van Wesenbeeck, C MacKay, A Mason-Savas, F F Safadi, S N Popoff, C Lengner, W van-Hul, Y Choi and S C Marks Int. J. Dev. Biol. (2001) 45: 853-859
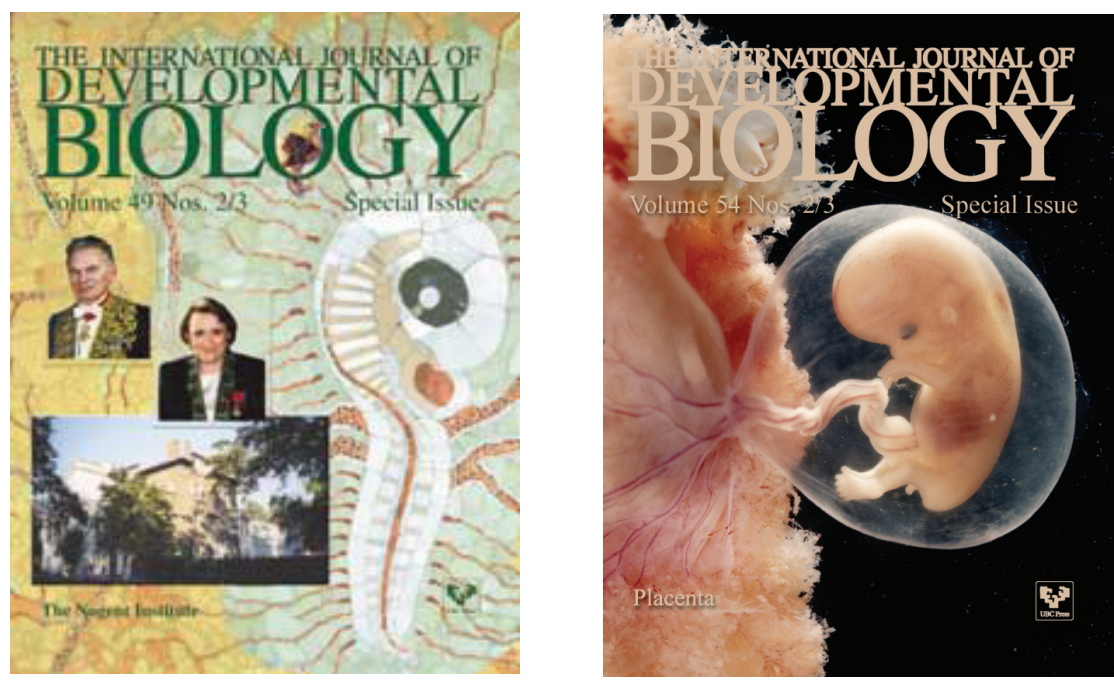

5 yr ISI Impact Factor $(2009)=3.253$

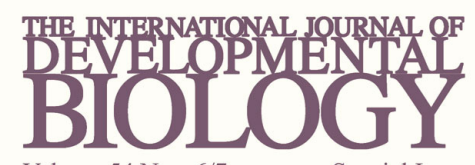

Volume 54 Nos. 6/7

Special Issue

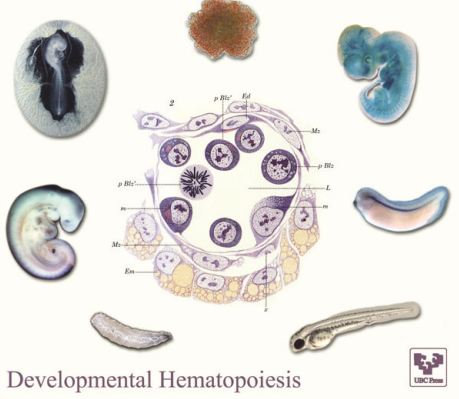

